\title{
The forgotten development: a discussion about the clean development mechanism and socioenvironmental sustainability
}

\author{
A. Sanches Pereira \\ Environment \& Sanitation Department - DSA, \\ School of Civil Engineering, Architecture and Urban Design - FEC, \\ State University of Campinas - UNICAMP, Brazil
}

\begin{abstract}
The concept of sustainable development (SD) has been broadened to become a new paradigm and form a hope for human impact mitigation. There is some consensus around its implementation; however, the imprecision of the SD concept causes worldwide debates regarding the diversity of adoption and understanding. In this context, the question is how we can shape the development process in order to make it capable of taking into consideration the local way of becoming sustainable. One recent attempt is the clean development mechanism (CDM) concept. This faces similar problems because the way in which the mechanism is used today does not fulfil its goal of assisting SD. Generally the mechanism is used only to meet the terms for emission reduction described in Article 3 of the Kyoto Protocol and does not contribute to the local society development. Consequently, it is necessary to develop a strategic plan for CDM's future implementation and repair its design failures by evaluating its current performance. An effective mechanism must integrate the socioenvironmental development concept into the implementation strategy. As a result, the new CDM must not only promote strict environmental sustainability, but also contribute to the reduction of poverty and social inequalities. This is because CDM will not be successful in the long term if it does not achieve the integration of social development with reduction of emissions.
\end{abstract}

Keywords: clean development mechanism, socioenvironmental strategic planning, socioenvironmental sustainability. 


\section{Introduction}

Environmental problems faced by modern society are not new, mankind has just recently been able to understand the complexity and interdependency of various factors. The more we learn, the more we find that current environmental problems are not isolated events which can be easily understood detached from other events. The factors involved that shape the problems are systemic, interlinked and interdependent [1]. To affect change requires broad perspectives and actions. At this moment in time, there is no precedent in history, nor is there an ultimate answer or consensus for solution of problems [2]. The environmental changes in progress today have developed in just a few decades, and now the impacts are being felt worldwide. For the first time in history, economic activity across the world is extraordinarily extensive. This velocity generates environmental changes on a global scale [3]. As a result, rapid degradation of environmental quality is occurring before our eyes.

The environmental quality concept is based on the relation between human activities and the environment itself. The increasing speed of human actions and the environment's resilience - its capacity to return to balance - are the key elements of the biosphere's disturbances. This relationship is modifying vital ecosystems and, recently, modifying earth's climate. Even though we are surrounded by many uncertainties, there is a general agreement that man represents the most powerful force of transformation on earth [4]. Man's influence on environmental quality depends on two factors: (i) the impact he has and (ii) the effort to undo or mitigate that impact [5]. Pearce [6] emphasizes that impacts are made indistinguishably by both poverty expansion and wealth accumulation.

Poverty and social inequality have direct influence on environmental quality. Examples of impacts include precarious sanitary systems, the accumulation of domestic solid waste in neighbourhoods, land degradation, infectious illness, as well as resulting accidents that can be attributed to these conditions $[7,8]$. Generally, efforts towards mitigation of these social woes include actions with little or no environmental relationship. In fact, it can be the opposite. In principle, mitigating efforts are exclusively related to the social development and do not consider environmental development [9]. Therefore, development policies intentionally designed with either positive (or negative) environmental impact misinterpret Tinbergen's basic rule when their actions do not interlink social and environmental development strategies. The rule says that for every independent policy objective it is necessary to have an independent policy instrument [10] or "you cannot kill two birds with one stone". If accepted, this means that reducing poverty and social inequality will not contribute directly to environmental quality recovery and protection, or vice versa. However, Tinbergen's independence concept does not require unlinked actions. Thus, the problem with current development concepts is limitation.

The concept of sustainable development (SD) has been broadened to become a new paradigm and form a hope for human impact mitigation. There is some consensus around its implementation; however, the imprecision of the SD 
concept causes worldwide debates regarding diversity of adoption and understanding. Debate varies from discussion about the neoclassic economy concept's incompatibility in incorporating the sustainability values, to the need of using differentiated economic theories to analyze the SD implementation [11] [12]. Others question the iniquity of the current standard of development and its unfeasibility as model to be followed in search of sustainability $[13,14]$. They maintain that there is a need for social strategies and policies that should be based on ethical posture of development $[15,16]$.

Clearly, the SD concept does not have an exclusive form of implementation. The model that is used in industrialized countries cannot be adopted as a solution for less industrialized countries [17] because any development process is closely related to the cultural background where it is implemented $[18,19]$. These factors cannot be evaluated independently. The priorities of less developed nations are different, and for that reason their priorities are sometimes forgotten.

In this context of experimentation based on experience, a new option has recently entered the scenario: carbon trading. This represents both a new challenge as well as a hope to the world's economies: a new market system, created by the Kyoto Protocol, which allows polluting companies to compensate their emissions by purchasing carbon credits - such as emission reduction units (ERUs) and/or certified emission reductions (CERs) - in order to meet the emission standards. The Protocol allows developed country participants to gain CERs if they assist developing countries reduce their own emissions. The assistance may vary from concessions to incentives to cleaner technology. As a result, developing countries use the clean development mechanism (CDM) as a voluntary instrument of emissions abatement to generate credits destined for either present or future transactions. The Kyoto Protocol has created the international carbon trading scheme, allowing industrialized countries to commercialize ERUs among emitters, as well as obtain CERs from less industrialized countries.

\section{The forgotten development aspect of CDM}

The purpose of the clean development mechanism (CDM) is to assist less developed countries achieve sustainable development and contribute to the ultimate objective of the Kyoto Protocol, which is to achieve compliance with each individual country's quantified emission limitation and reduction commitment [20].

In order to understand the CDM's challenge, it is necessary beforehand to discuss methods of SD implementation. Acselrad [16] suggests two ways of reaching SD. The first considers a development that subordinates the citizens of a country to the economic logic. As a result, the process depends on a development based on innovation, information circulation, and technological knowledge updating. In contrast, a second method elevates the society towards development through a frontal attack on poverty and social inequality.

At present, the first option has been adopted worldwide as development model. This model is directly related to the current technological acceleration in 
which modern society has become accustomed to through multiple advances in all areas of human knowledge [21]. One example is the resource flow within the futures market; the flow of matter is transformed into financial instruments indicating directions. The actual flow - a product of nature - is dematerialized into an abstract product of quantified information [22]. As a result, mankind's faith in the technology produces a world dematerialized, moving with exponential acceleration. Space and the substance give way to information. Sustainability based on technology requires access to technology, and thereby information in order to develop.

In contrast, the second option focuses on the local instead of the global reality. This is because the model chosen is based more on the community perspective and less on the globalisation vision of development. This means carefully planning the development instead of simply being lead by economic factors. Sustainability based on social development requires connecting social and environmental improvement with the local reality. This development process relies on a government that is empowered with regulatory capacity and democratic legitimacy [16]. The previously mentioned faith in technology and commerce is replaced by faith in mankind, with careful balances to prevent corruption and misappropriation of funds.

However, the mechanism does not inherently support either option, and it is generally used only to meet the terms for emission reduction as described in the Protocol. It hardly contributes to local societal development at all.

The development process must evolve in order to make it capable of taking into consideration the local way of becoming sustainable, and be complemented instead of being driven by the implementation of new technology.

One possible answer is to make socioenvironmental development a prime strategy. This third option of development model would be designed to join ideas of environmental policies and strategies to include and engage local communities, addressing their needs and knowledge [23]. Such a strategy that unites social and technological development needs a singular tool to promote it as well. The proposed tool is the social technology (ST).

Socioenvironmental development would occur through community interaction. This interaction represents an effective solution for social transformation [24] and includes a participatory process to built the local knowledge, science, and technology. ST would aim to achieve real sustainable development based upon and accomplished through human possibilities. It could be considered as an alternative intervention method in the society [25].

These three options of reaching sustainability represent three different implementations of the CDM objectives. It is proposed that a graphic representation be used to distinguish these effects. The graphic uses the objectives as the axis. The axis " $\mathrm{X}$ " addresses the compliance with the quantified emission limitation and reduction commitments. The axis "Y" shows the assistance to less developed countries in achieving SD. The points represented by the symbols $(+)$ and $(-)$ indicate whether the objective is achieved or not. It is necessary to have two points $(+)$ in order to reach both objectives, see Figure 1. 


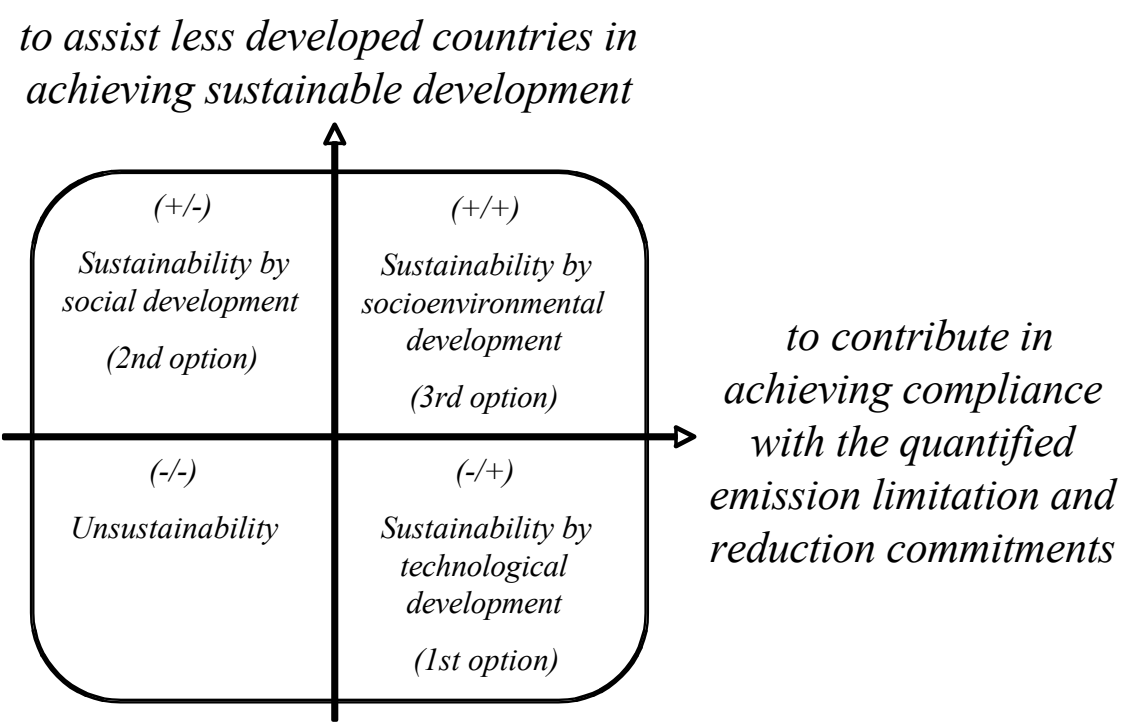

Created by the author

Figure 1: The socioenvironmental sustainability.

Figure 1 shows the socioenvironmental development represented by two points (+), meaning that both objectives are met. This is because the access to technology has become so vital in our modern society that both the social inclusion and the maintenance of the environmental quality cannot be achieved without technology. However, this process has to consider the adaptation capacity of individuals and populations to the technological advances [26]. It is important to consider that the technological wave affects the developing countries in a very different way to how it affects the industrialized countries [17]. For this reason, the joining of technology and the community-centred perspective is necessary, and ST could stimulate that process.

\section{Closing remarks}

This article attempted to provide an expanded perspective of CDM's objectives. It did so by pointing out that the SD concept does not have an exclusive form of implementation, and by proposing an alternative approach - socioenvironmental development, which is more sustainable in economic, social, and environmental terms. This article has attempted to provide a sense of the many shapes that CDM could adopt, as well as the impacts that could be achieved in reaching its goal. It has proposed a new development strategy - socioenvironmental development - and an implementation tool - social technology. 
It is intrinsic to the concept proposed in this paper that, in order for CDM to achieve a positive impact in less developed countries, it has to consider regional realities that are characterized by both human and technological poverty. Any SD strategy must satisfy the basic necessities of the low-income population. This is because viability of sustainability depends on "global thought, local action". It requires coordination of the two goals. This process must not only promote strict environmental sustainability, but also social and economic sustainability. In the case of less developed countries, the only way to do this is to contribute to the reduction of poverty and social inequality [27]. Consequently, it is necessary to develop a strategic plan for CDM's future implementation that will repair design failures by taking into account current performance.

An effective mechanism must integrate the socioenvironmental development concept into the implementation strategy. As stated earlier, the new CDM must not only promote strict environmental sustainability, but also contribute to the reduction of poverty and social inequalities. Countries such as Brazil, China, India and Indonesia are currently the greatest emitters. These developing countries cannot remain at the edge of the global effort to reduce greenhouse gases emissions, nor can their local problems be simply forgotten.

\section{References}

[1] Capra, F., A teia da vida: uma compreensão científica dos sistemas vivos, Editora Cultrix: São Paulo. 1996.

[2] Morin, E., A cabeça bem-feita. Repensar a reforma, reformar o pensamento, Editora Bertrand Brasil: Rio de Janeiro. 2000.

[3] Gardner, G., Acelerando a mudança para a sustentabilidade. Relatório do Worldwatch Institute Report - O estado do Mundo 2001, UMA: Salvador, p.206-225, 2001.

[4] Drew, D., Processos interativos homem-meio ambiente, Editora Bertrand Russel: São Paulo, 1989.

[5] Baumol, W.J. \& Oates, W.E., The theory of Environmental Policy: Externalities, Public Outlays, and Quality of Life, Prentice-Hall: Englewoods Cliffs - NJ, 1975.

[6] Pearce, D.W., Economics, equity and sustainable development. Futures, 20(6), p.598-605, 1988.

[7] Muller, C.C., Problemas ambientais de um estilo de desenvolvimento: a degradação da pobreza no Brasil. Ambiente \& Sociedade Ano I-No. 1, eds. Jacobi, P. R. \& Ferreira, L. C., Unicamp: Campinas, 1997.

[8] Pearce, D.W., The social incidence of environmental cost and benefits. Progress in Environmental Planning and Resource Management, ed. O’Riordan \& Turner, R.K. John Wiley and Sons Ltd: United Kingdom, p.63-87, 1980.

[9] Martinez-Alier, J., Justiça e distribuição ecológica de conflitos. A sociologia do século XXI, ed. Ferreira, L.C., Boitempo: São Paulo. p.122135, 1997.

[10] Tinbergen, J., On the Theory of Economic Policy, North Holland Press: Amsterdam, 1952. 
[11] Daly, H. E. \& Townsend, K. N., (eds). Valuing the Earth: Economics, Ecology, Ethics, Massachusetts Institute of Technology - MIT, 1994.

[12] Daly, H. E. \& Farley, J., Ecological Economics: principles and applications, Island Press: Washington - DC, 2004.

[13] O'Connor, J., Is sustainable capitalism possible? Is capitalism sustainable? - political economy and the politics of ecology, ed. O'Connor, M., The Guilfor Press: New York, p.152-173, 1997.

[14] Guimarães, R. P., Desenvolvimento sustentável: da retórica à formulação de políticas públicas. A geografia política do Desenvolvimento Sustentável, eds. Becker, B. K. \& Miranda, M. (Org.), Editora UFRJ: Rio de Janeiro, p.13-44, 1997.

[15] Sachs, I., Desenvolvimento includente, sustentável, sustentado, Editora Garamond Universitária/SEBRAE: Rio de Janeiro, 2004.

[16] Acselrad, H., Políticas ambientais e construção democrática. O desafio da sustentabilidade: Um debate socioambiental no Brasil, eds. Viana, G.; Silva, M. \& Diniz, N., Editora Fundação Perseu Abramo: Brasil, p. 75-96, 2001.

[17] Gallopín, G.C., Medio ambiente, desarrollo y cambio tecnológico en la América Latina. El futuro ecológico de un continente: una visión prospectiva de la América Latina. Segunda parte: Relación sociedadnaturaleza, ed. Gallopín, G.C., Editorial de la Universidad de las Naciones Unidas: México. p.483-539, 1995.

[18] Moore, D.S., Marxism, Culture and Political Ecology: Environmental struggles. Liberation Ecologies - environment, development and social movements: Zimbabwe's Eastern Highlands, ed. Peet, R. \& Watts, M., Routledge: New York, p.125-141, 1996.

[19] World Commission on Environment and Development (WCED), Our Common Future. Oxford University Press: Oxford, 1987.

[20] United Nations (UN), Kyoto Protocol to the United Nations Framework Convention on Climate Change. United Nations Press: New York, 1998.

[21] Kurzweil, R. \& Meyer, C., Understanding the accelerating rate of change. Online. www.kurzweilai.net/articles/art0563.html?printable=1

[22] Wark, M., Virtual geography, Indiana University Press: Bloomingnton, 1994.

[23] Santilli, J., Socioambientalismo e Novos Direitos: Proteção jurídica à diversidade biológica e cultural. Instituto Internacional de Educação do Brasil e Instituto Socioambiental: Peirópolis - SP, 2005.

[24] Dagnino, R., A tecnologia social e seus desafios. Tecnologia Social: uma estratégia para o desenvolvimento, ed. Fundação Banco do Brasil, FBB: Brasília, p.187-209, 2004.

[25] Rede de Tecnologia Social (RTS), www.rts.org.br

[26] Santos, L. G., Politizar as novas tecnologias: o impacto sócio-técnico da informação digital e genética. Editora 34: Brasil, 2003.

[27] Comissão de Desenvolvimento e Meio Ambiente da América Latina e do Caribe, Nossa Própria Agenda, Linha Gráfica Editora Ltda: Brasília, 1990. 